\title{
The Role of Thymic Stromal Lymphopoietin (TSLP) in Allergic Disorders
}

\author{
Steven F. Ziegler \\ Immunology Program, Benaroya Research Institute, Seattle, WA 98101, \\ sziegler@benaroyaresearch.org
}

\section{Summary}

The importance of the epithelium in initiating and controlling immune responses is becoming more appreciated. For example, allergens contact first occurs at mucosal sites in exposed to the external environment such as the skin, airways and gastrointestinal tract. This exposure leads to the production of a variety of cytokines and chemokines that are involved in driving allergic inflammatory responses. One such product is thymic stromal lymphopoietin (TSLP). Recent studies, in both humans and mouse models, have implicated TSLP in the development and progression of atopy and atopic diseases. This review will discuss this work and place TSLP in the inflammatory cascade that leads to allergic disease.

\section{Introduction}

The atopic diseases consist of the triad of asthma, allergic rhinitis, and atopic dermatitis. These diseases share a common pathogenesis, involving inflammatory Th2-type cytokines and elevated IgE. Interestingly, they frequently present together in the same individual and family, suggesting common factors and mechanisms are involved in these diseases. Recent evidence has been accumulated to suggest that Th2-type CD4+ T cells play a triggering role in the activation and/or recruitment of IgE antibody-producing B cells, mast cells and eosinophils, i.e. the cellular triad involved in the allergic inflammation. However, the mechanisms underlying the preferential activation by environmental allergens of Th2 cells in atopic individuals still remain obscure.

One possible candidate for a factor involved in the initiation of allergic inflammatory responses is the cytokine thymic stromal lymphopoietin (TSLP). TSLP is expressed by epithelial cells, with the highest levels seen in lung and skin-derived epithelial cells[1]. Studies using human CD11 $\mathrm{c}^{+}$dendritic cells showed that these cells produced CCL17 and CCL22 following exposure to TSLP, chemokines capable of attracting Th2-type CD4 ${ }^{+} \mathrm{T}$ cells[1;2]. In addition, when CD4 ${ }^{+} \mathrm{T}$ cells are primed on TSLP-treated DCs they take on an inflammatory Th2 phenotype, producing IL-4, IL-5, IL-13, and TNF- $\alpha$ upon restimulation[2]. Notably, lesional, but not unaffected, skin from patients with atopic dermatitis express high levels of TSLP. The DCs in the affected skin have left the epidermis and have acquired an activated phenotype.

\footnotetext{
() 2010 Elsevier Ltd. All rights reserved.
}

Publisher's Disclaimer: This is a PDF file of an unedited manuscript that has been accepted for publication. As a service to our customers we are providing this early version of the manuscript. The manuscript will undergo copyediting, typesetting, and review of the resulting proof before it is published in its final citable form. Please note that during the production process errors may be discovered which could affect the content, and all legal disclaimers that apply to the journal pertain. 


\section{TSLP Biology}

Thymic stromal lymphopoietin (TSLP) is a member of the cytokine family, most closely related to IL-7. Identified in the culture supernatant of a mouse thymic stromal cell line, it was initially studied as a B cell growth factor [3;4]. In addition, several groups identified a TSLP-binding protein in the mouse, referred to as TSLPR, with sequence analysis showing that TSLPR was similar to the common cytokine receptor $\gamma$ chain $\left(\gamma_{c}\right)$ [5]. TSLPR was capable of binding TSLP with low affinity, and further analysis of the TSLP receptor complex showed that the high affinity, functional receptor included the IL-7R $\alpha$ chain, further linking these cytokines. Subsequently, analysis of sequence databases was used to isolate clones of human TSLP and TSLPR[1;6]. The human and mouse proteins were found to be quite divergent at the sequence level, but, as will be discussed below, they are functionally similar.

Expression of the cytokine and receptor complex is similar between humans and mice. Epithelial cells at barrier surfaces were found to be the principle source of TSLP ${ }^{23}$, although additional cell populations are capable of expressing the cytokine. The receptor is expressed broadly on a wide variety of hematopoietic lineage cell populations, including dendritic cells, monocyte/macrophages, B cells, T cells, basophils, and eosinophils[1;7]. However, expression is not limited to hematopoietic cells as structural cells have been shown to respond to TSLP in vitro[8].

Little is known as to the signaling pathways that are activated following engagement of the TSLP receptor complex. Initial studies in the mouse showed that Stat5 was activated, but in the absence of detectable Jak activation[4], making TSLPR unique among members of the hematopoietic receptor family. While several pathways and signaling molecules have been implicated in signaling downstream of the mouse TSLPR, including Src kinases and PI 3-K, direct evidence is lacking[9]. In the human, recent studies have shown that, in addition to STAT5, TSLP stimulation activated STAT 1,3,4,5, and 6, as well as JAKs 1 and 2[10]. One possible explanation for the discrepancy in the data between species is that the mouse signaling work used a pre-B cell line, while the human studies were in primary dendritic cells. Clearly, additional studies are required to reconcile these data.

\section{TSLP and Allergic Disease}

As described above, TSLP is a strong candidate to be a factor that mechanistically links allergic inflammatory diseases. As summarized below, much of the recent work on TSLP supports this role.

\section{Atopic dermatitis}

The association of TSLP with allergic disease first became apparent when Soumelis et al. [2] examined TSLP expression in the lesional skin of individuals with inflammatory skin disorders. They found that TSLP expression was significantly elevated in the epidermis of lesional skin from individuals with acute and chronic atopic dermatitis, but not in uninvolved skin or skin from patients with cutaneous lupus erythematous or nickel-induced dermatitis. Interestingly, cytokines that are found at high levels in lesional skin in these patients (IL-1 $\beta, \mathrm{TNF} \alpha$, IL-4 and IL-13) can also synergize to induce TSLP expression by keratinocytes[11], suggesting a feed-forward inflammatory cascade. In addition, in mouse models, mutations that alter skin barrier function also induce TSLP expression, leading to the development of an AD-like skin disease[12].

More recently, it was shown that patients with Netherton syndrome (NS), a severe icthyosis in which affected individuals experience a significant predisposition for atopic disease[13], 
have elevated levels of TSLP in their skin[14]. NS is caused by mutations in the serine protease inhibitior Kazal-type 5 (SPINK5) gene, which encodes the protease inhibitor lymphoepithelial Kazal-type-related inhibitor (LEKTI)[15]. LEKTI deficiency leads to dysregulation of the protease kallekrein 5, which in turn activates protease-activated receptor-2 (PAR-2). Activated PAR-2 has been shown to induce the expression of TSLP from either keratinocytes or airway epithelial cells[14;16]. Thus, a mutation that increases TSLP expression in the skin has direct consequences on the development of a severe atopic disease.

TSLP has also been associated with Th2-type skin inflammation in mouse models. Inducible expression of TSLP in the skin lead to the development of a spontaneous skin inflammatory disease with the hallmark features of $\mathrm{AD}[17]$. In an antigen driven model of dermatitis that also uses barrier disruption via tape-stripping $\mathrm{He}$ et al.[18] found that TSLP signaling was required for development of skin inflammation. These studies used mice lacking TSLPR, and it was lack of TSLP signaling in CD4 T cells as they infiltrate the skin that appeared to be responsible for the lack of a response.

The role of TSLP in FITC-mediated contact hypersensitivity, a Th2-mediated model of human allergic contact dermatitis, has recently been elucidated. TSLP expression is induced following priming with FITC. The induction of TSLP gene expression is mediated by a component of the solvent used to dissolve the FITC, dibutyl phthalate[19-21]. TSLPRdeficient mice failed to mount a response following challenge, as did mice where TSLP was neutralized during both priming and challenge[19]. Blockade of TSLP during challenge alone partially reduced the response, suggesting that TSLP is required at both priming and challenge to generate a complete response[21]. Unlike the tape-stripping model, in this system a defect was found in skin resident dendritic cells in TSLPR-deficient mice. Antigenbearing dendritic cells from TSLPR ${ }^{-1}$ mice displayed a migration defect as well as a reduced capacity to drive CD4 T cell proliferation[19]. TSLPR-deficient CD4 T cells were indistinguishable from their wild-type counterparts in their ability to proliferate and infiltrate the skin following FITC priming, suggesting that these cells do require direct TSLP responses to drive pathology in this model (SFZ and RP Larson, manuscript in preparation).

In addition to these transgenic and antigen-driven models of skin inflammation, TSLP has also been shown to be involved in 2 models using gene targeted mice. Mice that lack expression of the steroid receptors RXR $\alpha$ and $\mathrm{RXR} \beta$ specifically in keratinocytes were shown to develop a TSLP-dependent AD-like disease[22]. In the second model, epidermalspecific ablation of the Notch1 and 2, or the Notch binding partner RBP-j, resulted in loss of skin barrier function and TSLP-driven skin inflammation[12;23]. While the mechanism by which TSLP was induced by loss of the Notch pathway is not known, these studies show that TSLP induction is a component of the cellular response to skin damage.

\section{Asthma}

The first association of TSLP with inflammation of the airways was demonstrated using mice expressing a TSLP transgene in the airway epithelium. These mice develop a spontaneous, progressive inflammatory disease with all the characteristics of human asthma[24]. The disease in these mice develops slowly over a three month period, based on adaptive responses to environmental antigens, and challenge at an early age with antigen leads to immediate onset of disease[24;25]. These data suggest that TSLP is functioning to condition the local environment to respond to aero-antigens. Consistent with the mouse data, several studies have now shown that human asthmatics have increased concentrations of TSLP in their lungs[26-28]. 
The most compelling evidence for the importance of TSLP in the development of airway inflammation comes from genetic studies using mice. TSLPR-deficient mice are resistant to the development of inflammation in the classical OVA plus Alum priming model in mice[24;29]. It has been suggested that this is due to the inability of $\mathrm{CD}^{+} \mathrm{T}$ cells to respond to TSLP as reconstitution with TSLPR-sufficient T cells restored aspects of the inflammatory disease [29]. Taken together with the data from TSLP overexpression in the lung, these data show that TSLP is both necessary and sufficient for the development of asthma-like airway inflammatory disease in mice.

Consistent with the link between TSLP and airway inflammation, factors known to be involved in either the development of asthma, or the exacerbation of existing disease, can induce TSLP expression by airway epithelial cells. These factors include inflammatory cytokines present in asthmatic lungs (IL-1 $\beta, \mathrm{TNF} \alpha$, IL-4, IL-13 and IL-25), fungal proteases[16], and respiratory viruses (MB Headley, H-C Lee, and SFZ, manuscript in preparation and [30-32]). The finding that respiratory syncytial virus infection can induce TSLP expression is especially interesting as it has been linked to both development of wheezing, and subsequent asthma, in infants and asthma exacerbations in affected individuals[33-36]. There is also genetic evidence of a link between TSLP and asthma as several genome wide studies have found polymorphisms in the TSLP gene associated with aspects of asthma in human populations[37-41].

\section{TSLP and other allergic diseases}

In addition to $\mathrm{AD}$ and asthma, elevated TSLP expression has been seen in a variety of other allergic inflammatory conditions. These include allergic rhinitis[42;43], food allergy[44], allergic conjunctivitis[45;46], and the response to a wide variety of allergens[47-50]. In addition, TSLP has been associated genetically with eosinophilic esophagitis, a Th2-type inflammatory disease of the esophagus[51;52].

\section{TSLP and the atopic march}

It has been well documented that atopic diseases present sequentially in humans, a phenomenon referred to as the atopic march[53]. Based on its role in allergic diseases in both skin and lung, TSLP is a prime candidate for a factor involved in this process. Two groups have recently published mouse models examining the possible role of skin-derived TSLP in airway inflammatory responses $([54 ; 55]$. Both studies showed that mice with TSLP-mediated AD-like disease showed exaggerated responses when challenged with allergen in the airways. Our group has similar data using the epidermal-specific inducible TSLP transgenic mice ([17] and H Han and SFZ, in preparation). However, a significant caveat in these animal models is the very high concentrations of circulating TSLP, which is not seen in individuals with AD. Thus, while an attractive hypothesis, it is not yet clear what role, if any, TSLP plays in the atopic march.

\section{Conclusions}

The role of TSLP in allergic inflammation is an area of intense investigation now. The data, as reviewed above, strongly suggests that TSLP plays a critical role in the induction of allergic disease. However, its potential role in disease progression is still somewhat unclear and will need to be elucidated. Equally important, what role TSLP plays in normal immune homeostasis remains to be determined. This point is critical in that it may determine whether TSLP blockade for the treatment of allergic diseases will be tolerated. Finally, it is now becoming clear that TSLP acts in concert with two other cytokines, IL-17E/IL-25 and IL-33, to drive Th2-type inflammation. Deciphering how these cytokines "talk" to each other, and how they are individually and collectively regulated, is critical. 


\section{Reference List}

1. Reche PA, Soumelis V, Gorman DM, Clifford T, Liu M, Travis M, Zurawski SM, Johnston J, Liu YJ, Spits H, Waal Malefyt R, Kastelein RA, Bazan JF. Human thymic stromal lymphopoietin preferentially stimulates myeloid cells. J Immunol 2001;167:336-343. [PubMed: 11418668]

2. Soumelis V, Reche PA, Kanzler H, Yuan W, Edward G, Homey B, Gilliet M, Ho S, Antonenko S, Lauerma A, Smith K, Gorman D, Zurawski S, Abrams J, Menon S, McClanahan T, Waal-Malefyt RR, Bazan F, Kastelein RA, Liu YJ. Human epithelial cells trigger dendritic cell mediated allergic inflammation by producing TSLP. Nat.Immunol 2002;3:673-680. [PubMed: 12055625] . First paper to show role for TSLP in allergic disease, as well as first paper to show that dendritic cells are TSLP-responsive and drive inflammatory Th2 differentiation following maturation by TSLP

3. Friend SL, Hosier S, Nelson A, Foxworthe D, Williams DE, Farr A. A thymic stromal cell line supports in vitro development of surface IgM+ B cells and produces a novel growth factor affecting B and T lineage cells. Exp.Hematol 1994;22:321-328. [PubMed: 8112430]

4. Levin SD, Koelling RM, Friend SL, Isaksen DE, Ziegler SF, Perlmutter RM, Farr AG. Thymic stromal lymphopoietin: a cytokine that promotes the development of IgM+ B cells in vitro and signals via a novel mechanism. J.Immunol 1999;162:677-683. [PubMed: 9916685]

5. Pandey A, Ozaki K, Baumann H, Levin SD, Puel A, Farr AG, Ziegler SF, Leonard WJ, Lodish HF. Cloning of a receptor subunit required for signaling by thymic stromal lymphopoietin. Nat.Immunol 2000;1:59-64. [PubMed: 10881176]

6. Quentmeier H, Drexler HG, Fleckenstein D, Zaborski M, Armstrong A, Sims JE, Lyman SD. Cloning of human thymic stromal lymphopoietin (TSLP) and signaling mechanisms leading to proliferation. Leukemia 2001;15:1286-1292. [PubMed: 11480573]

7. Park LS, Friend DJ, Schmierer AE, Dower SK, Namen AE. Murine interleukin 7 (IL-7) receptor: characterization on an IL-7-dependent cell line. J Exp Med 1990;171:1073-1089. [PubMed: 2324686]

8. Semlali A, Jacques E, Koussih L, Gounni AS, Chakir J. Thymic stromal lymphopoietin-induced human asthmatic airway epithelial cell proliferation through an IL-13-dependent pathway. J Allergy Clin Immunol 2010;125:844-850. [PubMed: 20236697]

9. Isaksen DE, Baumann H, Zhou B, Nivollet S, Farr AG, Levin SD, Ziegler SF. Uncoupling of proliferation and Stat5 activation in thymic stromal lymphopoietin-mediated signal transduction. $\mathrm{J}$ Immunol 2002;168:3288-3294. [PubMed: 11907084]

10. Arima K, Watanabe N, Hanabuchi S, Chang M, Sun SC, Liu YJ. Distinct signal codes generate dendritic cell functional plasticity. Sci.Signal 2010;3:ra4. [PubMed: 20086239]

11. Bogiatzi SI, Fernandez I, Bichet JC, Marloie-Provost MA, Volpe E, Sastre X, Soumelis V. Cutting Edge: Proinflammatory and Th2 cytokines synergize to induce thymic stromal lymphopoietin production by human skin keratinocytes. J Immunol 2007;178:3373-3377. [PubMed: 17339431]

12. Demehri S, Liu Z, Lee J, Lin MH, Crosby SD, Roberts CJ, Grigsby PW, Miner JH, Farr AG, Kopan R. Notch-deficient skin induces a lethal systemic B-lymphoproliferative disorder by secreting TSLP, a sentinel for epidermal integrity. PLoS.Biol 2008;6:e123. [PubMed: 18507503]

13. Judge MR, Morgan G, Harper JI. A clinical and immunological study of Netherton's syndrome. Brit J Dermatol 1994;131:615-621. [PubMed: 7999590]

14. Briot A, Deraison C, Lacroix M, Bonnart C, Robin A, Besson C, Dubus P, Hovnanian A. Kallikrein 5 induces atopic dermatitis-like lesions through PAR2-mediated thymic stromal lymphopoietin expression in Netherton syndrome. J.Exp.Med 2009;206:1135-1147. [PubMed: 19414552] . First report to show a direct link between TSLP and a specific disease.

15. Chavanas S, Bodemer C, Rochat A, Hamel-Teillac D, Ali M, Irvine AD, Bonafe JL, Wilkinson J, Taieb AlBY, Harper JI, de Prost Y, Hovnanian A. Mutations in SPINK5, encoding a serine protease inhibitor, cause Netherton syndrome. Nature Genet 2000;25:141-142. [PubMed: 10835624]

16. Kouzaki H, O'Grady SM, Lawrence CB, Kita H. Proteases induce production of thymic stromal lymphopoietin by airway epithelial cells through protease-activated receptor-2. J Immunol 2009;183:1427-1434. [PubMed: 19561109] 
17. Yoo J, Omori M, Gyarmati D, Zhou B, Aye T, Brewer A, Comeau MR, Campbell DJ, Ziegler SF. Spontaneous atopic dermatitis in mice expressing an inducible thymic stromal lymphopoietin transgene specifically in the skin. J.Exp.Med 2005;202:541-549. [PubMed: 16103410]

18. He R, Oyoshi MK, Garibyan L, Kumar L, Ziegler SF, Geha RS. TSLP acts on infiltrating effector T cells to drive allergic skin inflammation. Proc.Natl.Acad.Sci.U.S.A 2008;105:11875-11880. [PubMed: 18711124]

19. Larson RP, Zimmerli SC, Comeau MR, Itano A, Iseki M, Hauser C, Ziegler SF. Dibutyl phthalateinduced thymic stromal lymphopoietin is required for th2 contact hypersensitivity responses. $\mathrm{J}$ Immunol 2010;184:2974-2984. [PubMed: 20173025] . These 3 papers demonstrate importance of keratinocyte-derived TSLP in development of skin inflammation.

20. Shigeno T, Katakuse M, Fujita T, Mukoyama Y, Watanabe H. Phthalate ester-induced thymic stromal lymphopoietin mediates allergic dermatitis in mice. Immunology 2009;128:e849-e857. [PubMed: 19740346]

21. Boehme SA, Franz-Bacon K, Chen EP, Sasik R, Sprague LJ, Ly TW, Hardiman G, Bacon KB. A small molecule CRTH2 antagonist inhibits FITC-induced allergic cutaneous inflammation. Int.Immunol 2009;21:81-93. [PubMed: 19066314]

22. Li M, Messaddeq N, Teletin M, Pasquali JL, Metzger D, Chambon P. Retinoid X receptor ablation in adult mouse keratinocytes generates an atopic dermatitis triggered by thymic stromal lymphopoietin. Proc.Natl.Acad.Sci.U.S.A 2005;102:14795-14800. [PubMed: 16199515]

23. Dumortier A, Durham AD, Di Piazza M, Vauclair S, Koch U, Ferrand G, Ferrero I, Demehri S, Song LL, Farr AG, Leonard WJ, Kopan R, Miele L, Hohl D, Finke D, Radtke F. Atopic dermatitis-like disease and associated lethal myeloproliferative disorder arise from loss of notch signaling in the murine skin. PLoS.ONE 2010;5:e9258. [PubMed: 20174635]

24. Zhou B, Comeau MR, De Smedt T, Liggitt HD, Dahl ME, Lewis DB, Gyramati D, Aye T, Campbell DJ, Ziegler SF. Thymic Stromal Lymphopoietin (TSLP) as a Key Initiator of Allergic Airway Inflammation in Mice. Nat Immunol 2005;6:1047-1053. [PubMed: 16142237]

25. Headley MB, Zhou B, Shih WX, Aye T, Comeau MR, Ziegler SF. TSLP conditions the lung immune environment for the generation of pathogenic innate and antigen-specific adaptive immune responses. J.Immunol 2009;182:1641-1647. [PubMed: 19155513] . Along with reference 29 , these papers show that TSLP is both necessary and sufficient to drive Th2-type airway inflammation.

26. Ying S, O'Connor B, Ratoff J, Meng Q, Mallett K, Cousins D, Robinson D, Zhang G, Zhao J, Lee $\mathrm{TH}$, Corrigan C. Thymic stromal lymphopoietin expression is increased in asthmatic airways and correlates with expression of Th2-attracting chemokines and disease severity. J.Immunol 2005;174:8183-8190. [PubMed: 15944327]

27. Ying S, O'Connor B, Ratoff J, Meng Q, Cousins D, Zhang G, Gu S, Gao Z, Shamji B, Edwards MJ, Lee TH, Corrigan CJ. Expression and cellular provenance of thymic stromal lymphopoietin and chemokines in patients with severe asthma and chronic obstructive pulmonary disease. $\mathbf{J}$ Immunol 2008;181:2790-2798. [PubMed: 18684970]

28. Fang C, Siew LQ, Corrigan CJ, Ying S. The role of thymic stromal lymphopoietin in allergic inflammation and chronic obstructive pulmonary disease. Arch.Immunol.Ther.Exp.(Warsz.) 2010;58:81-90. [PubMed: 20143171]

29. Al Shami A, Spolski R, Kelly J, Keane-Myers A, Leonard WJ. A role for TSLP in the development of inflammation in an asthma model. J.Exp.Med 2005;202:829-839. [PubMed: 16172260]

30. Lee HC, Ziegler SF. Inducible expression of the proallergic cytokine thymic stromal lymphopoietin in airway epithelial cells is controlled by NFkappaB. Proc.Natl.Acad.Sci.U.S.A 2007;104:914-919. [PubMed: 17213320]

31. Kato A, Favoreto S Jr, Avila PC, Schleimer RP. TLR3- and Th2 cytokine-dependent production of thymic stromal lymphopoietin in human airway epithelial cells. J Immunol 2007;179:1080-1087. [PubMed: 17617600]

32. Qiao J, Li A, Jin X. TSLP from RSV-stimulated rat airway epithelial cells activates myeloid dendritic cells. Immunol.Cell Biol. 2010

33. Holt PG, Sly PD. Interactions between RSV infaction, asthma, and atopy: unraeling the complexities. J Exp Med 2002;196:1271-1275. [PubMed: 12438419] 
34. Hall CB. Respiratory syncytial virus and parainfluenza virus. N Eng J Med 2001;344:1917-1928.

35. Martinez FD. Respiratory syncytial virus bronchiolotis and the pathogenesis of childhood asthma. Pediart Inf Dis J 2003;22:S76-S82.

36. Stein RT, Sherrill D, Morgan WJ, Holberg CJ, Halonen M, Taussig LM, Wright AL, Martinez FD. Respiratory syncytial virus in early life and risk of wheeze and allergy by age 13 years. Lancet 1999;354:541-545. [PubMed: 10470697]

37. Hunninghake GM, Soto-Quiros ME, Avila L, Kim HP, Lasky-Su J, Rafaels N, Ruczinski I, Beaty TH, Mathias RA, Barnes KC, Wilk JB, O'Connor GT, James GW, Vora H, Baurley JW, Gilliland F, Liang C, Sylvia JS, Klanderman BJ, Sharma SS, Himes BE, Bossley CJ, Israel E, Raby BA, Bush A, Choi AM, Weiss ST, Celedon JC. TSLP polymorphisms are associated with asthma in a sex-specific fashion. Allergy. 2010

38. Harada H, Hirota T, Jodo AI, Hitomi Y, Sakashita M, Tsunoda T, Miyagawa T, Doi S, Kameda M, Fujita K, Miyatake A, Enomoto T, Noguchi E, Masuko H, Sakamoto T, Hizawa N, Suzuki Y, Yoshihara S, Adachi M, Ebisawa M, Saito H, Matsumoto K, Nakajima T, Mathias RA, Rafaels N, Barnes KC, Himes BE, Duan QL, Tantisira KG, Weiss ST, Nakamura Y, Ziegler SF, Tamari M. TSLP Promoter Polymorphisms are Associated with Susceptibility to Bronchial Asthma. Am J Respir Cell Mol Biol. 2010 Epub ahead of print.

39. Harada M, Hirota T, Jodo AI, Doi S, Kameda M, Fujita K, Miyatake A, Enomoto T, Noguchi E, Yoshihara S, Ebisawa M, Saito H, Matsumoto K, Nakamura Y, Ziegler SF, Tamari M. Functional analysis of the thymic stromal lymphopoietin variants in human bronchial epithelial cells. Am.J.Respir.Cell Mol.Biol 2009;40:368-374. [PubMed: 18787178]

40. Hunninghake GM, Lasky-Su J, Soto-Quiros ME, Avila L, Liang C, Lake SL, Hudson TJ, Spesny M, Fournier E, Sylvia JS, Freimer NB, Klanderman BJ, Raby BA, Celedon JC. Sex-stratified linkage analysis identifies a female-specific locus for IgE to cockroach in Costa Ricans. Am.J.Respir.Crit Care Med 2008;177:830-836. [PubMed: 18244952]

41. Gudbjartsson DF, Bjornsdottir US, Halapi E, Helgadottir A, Sulem P, Jonsdottir GM, Thorleifsson G, Helgadottir H, Steinthorsdottir V, Stefansson H, Williams C, Hui J, Beilby J, Warrington NM, James A, Palmer LJ, Koppelman GH, Heinzmann A, Krueger M, Boezen HM, Wheatley A, Altmuller J, Shin HD, Uh ST, Cheong HS, Jonsdottir B, Gislason D, Park CS, Rasmussen LM, Porsbjerg C, Hansen JW, Backer V, Werge T, Janson C, Jonsson UB, Ng MC, Chan J, So WY, Ma R, Shah SH, Granger CB, Quyyumi AA, Levey AI, Vaccarino V, Reilly MP, Rader DJ, Williams MJ, van Rij AM, Jones GT, Trabetti E, Malerba G, Pignatti PF, Boner A, Pescollderungg L, Girelli D, Olivieri O, Martinelli N, Ludviksson BR, Ludviksdottir D, Eyjolfsson GI, Arnar D, Thorgeirsson G, Deichmann K, Thompson PJ, Wjst M, Hall IP, Postma DS, Gislason T, Gulcher J, Kong A, Jonsdottir I, Thorsteinsdottir U, Stefansson K. Sequence variants affecting eosinophil numbers associate with asthma and myocardial infarction. Nat.Genet 2009;41:342-347. [PubMed: 19198610]

42. Mou Z, Xia J, Tan Y, Wang X, Zhang Y, Zhou B, LI H, Han D. Overexpression of thymic stromal lymphopoietin in allergic rhinitis. Acta Otolaryngol 2009;129:297-301. [PubMed: 18720075]

43. Miyata M, Hatsushika K, Ando T, Shimokawa N, Ohnuma Y, Katoh R, Suto H, Ogawa H, Masuyama K, Nakao A. Mast cell regulation of epithelial TSLP expression plays an important role in the development of allergic rhinitis. Eur.J.Immunol 2008;38:1487-1492. [PubMed: 18461563]

44. Blazquez AB, Mayer L, Berin MC. Thymic Stromal Lymphopoietin is Required for Gastrointestinal Allergy but not Oral Tolerance. Gastroenterology. 2010

45. Zheng X, Ma P, de Paiva CS, Cunningham MA, Hwang CS, Pflugfelder SC, Li DQ. TSLP and downstream molecules in experimental mouse allergic conjunctivitis. Invest Ophthalmol.Vis.Sci 2010;51:3076-3082. [PubMed: 20107175]

46. Matsuda A, Ebihara N, Yokoi N, Kawasaki S, Tanioka H, Inatomi T, de Waal MR, Hamuro J, Kinoshita S, Murakami A. Functional role of thymic stromal lymphopoietin in chronic allergic keratoconjunctivitis. Invest Ophthalmol.Vis.Sci 2010;51:151-155. [PubMed: 19741251]

47. Hulse KE, Reefer AJ, Engelhard VH, Partie JT, Ziegler SF, Chapman MD, Woodfolk JA. Targeting allergen to FcãRI reveals a novel TH2 regulatory pathway linked to thymic stromal lymphopoietin receptor. J Allergy Clin Immunol 2010;125:247-256. [PubMed: 20109752] 
48. Zhu DD, Zhu XW, Jiang XD, Dong Z. Thymic stromal lymphopoietin expression is increased in nasal epithelial cells of patients with mugwort pollen sensitive-seasonal allergic rhinitis. Chin Med.J.(Engl.) 2009;122:2303-2307. [PubMed: 20079130]

49. Corrigan CJ, Jayaratnam A, Wang Y, Liu Y, de Waal MR, Meng Q, Kay AB, Phipps S, Lee TH, Ying S. Early production of thymic stromal lymphopoietin precedes infiltration of dendritic cells expressing its receptor in allergen-induced late phase cutaneous responses in atopic subjects. Allergy 2009;64:1014-1022. [PubMed: 19187393]

50. Seshasayee D, Lee WP, Zhou M, Shu J, Suto E, Zhang J, Diehl L, Austin CD, Meng YG, Tan M, Bullens SL, Seeber S, Fuentes ME, Labrijn AF, Graus YM, Miller LA, Schelegle ES, Hyde DM, Wu LC, Hymowitz SG, Martin F. In vivo blockade of OX40 ligand inhibits thymic stromal lymphopoietin driven atopic inflammation. J.Clin.Invest 2007;117:3868-3878. [PubMed: 18060034]

51. Sherrill JD, Gao PS, Stucke EM, Blanchard C, Collins MH, Putnam PE, Franciosi JP, Kushner JP, Abonia JP, Assa'ad AH, Kovacic MB, Biagini Myers JM, Bochner BS, He H, Hershey GK, Martin LJ, Rothenberg ME. Variants of thymic stromal lymphopoietin and its receptor associate with eosinophilic esophagitis. J.Allergy Clin.Immunol 2010;126:160-165. [PubMed: 20620568]

52. Rothenberg ME, Spergel JM, Sherrill JD, Annaiah K, Martin LJ, Cianferoni A, Gober L, Kim C, Glessner J, Frackelton E, Thomas K, Blanchard C, Liacouras C, Verma R, Aceves S, Collins MH, Brown-Whitehorn T, Putnam PE, Franciosi JP, Chiavacci RM, Grant SF, Abonia JP, Sleiman PM, Hakonarson H. Common variants at $5 \mathrm{q} 22$ associate with pediatric eosinophilic esophagitis. Nat.Genet 2010;42:289-291. [PubMed: 20208534]

53. Spergel JM, Paller AS. Atopic dermatitis and the atopic march. J Allergy Clin Immunol 2003;112:S118-S127. [PubMed: 14657842]

54. Demehri S, Morimoto M, Holtzman MJ, Kopan R. Skin-derived TSLP triggers progression from epidermal-barrier defects to asthma. PLoS.Biol 2009;7:e1000067. [PubMed: 19557146]

55. Zhang Z, Hener P, Frossard N, Kato S, Metzger D, Li M, Chambon P. Thymic stromal lymphopoietin overproduced by keratinocytes in mouse skin aggravates experimental asthma. Proc.Natl.Acad.Sci.U.S.A 2009;106:1536-1541. [PubMed: 19188585] . These papers provide indication that elevated circulating TSLP, derived from keratinocytes, can affect responses to aeroantigens, implicating TSLP in the atopic march. 